\title{
Technological aspects of the development of gas hydrate deposits with the use of carbon dioxide injection
}

\author{
Kostiantyn Ganushevych ${ }^{1}$, and Kateryna Sai $^{2 *}$ \\ ${ }^{1}$ Colorado School of Mines, Department of Chemical and Biological Engineering, 1500 Illinois St., \\ Alderson Hall, CO 80401, Golden, United States \\ ${ }^{2}$ Dnipro University of Technology, Department of Mining Engineering and Education, \\ 19 Yavornytskoho, 49005 Dnipro, Ukraine
}

\begin{abstract}
The article is dedicated to the technological peculiarities of natural gas hydrate deposits extraction with using perspective method which consists of introduction of carbon dioxide into the gas hydrate layer removing methane and creating $\mathrm{CO}_{2}$ hydrate. Specific attention is paid to the insufficient efficiency of presently used methods in terms of the economic effect and safety of gas extraction. The complex methodological approach has been used to experimentally determine the optimal pressure of the two gases swap based on the minimal time of the process duration. The rate of the two gases exchange in the reactor has been defined and a new technological solution as to the gas hydrate deposits recovery has been proposed. It is defined that at the pressure being equal to $P=9 \mathrm{MPa}$ and the temperature $T=+7 \ldots+8^{\circ} \mathrm{C}$, the whole exchange of the guest molecules $\mathrm{CH}_{4}$ for $\mathrm{CO}_{2}$ molecules can be reached in 2 hours. It is established that the gas hydrate crystallisation centres nucleate in about $30-35$ minutes, after that the crystals continue growing removing methane from the preliminary created hydrate up to the point when about $70-80 \%$ of the hydrate is filled with $\mathrm{CO}_{2}$ hydrate. The lowest rate of the exchange process took place under the pressure $P=5 \mathrm{MPa}$ and temperature $T=+7 \ldots+8^{\circ} \mathrm{C}$ and resulted in 10 hours. The penetration length of the carbon dioxide jet is established depending on the process duration under the optimal injection pressure of $\mathrm{CO}_{2}$. A new technological scheme is introduced for methane recovery from gas hydrate deposits of the Black Sea with the help of carbon dioxide injection into the hydrate seam.
\end{abstract}

\section{Introduction}

Under the modern conditions of an intensive consumption of energy it is apparent that already in the nearest future the humanity will deplete most of the discovered deposits of natural gas $[1,2]$. In connection with this, the world scientific society is actively researching the possibility of the alternative types of fuel usage and looking for additional sources of energy [3-5], and also the development of new approaches to economical and

\footnotetext{
${ }^{*}$ Corresponding author: kateryna.sai@gmail.com
} 
ecological strategies of mineral resources mining [6,7]. At present there is no alternative source of energy that can significantly reduce the influence of the traditional organic fuel for providing energy independence of modern countries. The future development of Ukraine's energy sector is directly connected to sufficient production level of both solid fuels by various methods [8-10], and hydrocarbon raw materials [11-13], having excavated which there is no industrial waste left [14]. Gas hydrate deposits excavation is quite a perspective direction that is already implemented in some countries [15-17], but in Ukraine it is only on the level of theoretical study [18, 19]. The gas hydrate deposits of the Black Sea pose a significant interest for Ukraine since the natural gas reserves concentrated in the Ukrainian share $\left(20-25 \mathrm{bln}^{3}\right)$ several times higher than present reserves of natural gas in traditional deposits that will allow to provide Ukraine with this energy carrier for several centuries considering all necessary demands for the industrial complex of both the government and the people [20 - 22].

Nowadays, there are three basic methods of the natural gas recovery from gas hydrate deposits in the world:

1) heating the gas hydrate host-rocks or the hydrate itself above the equilibrium temperature;

2) lowering the pressure to the point when it is less than the equilibrium pressure of gas hydrate stable existence;

3 ) introduction of inhibitors into the gas hydrate seam [23 - 25].

All of them are based on the dissociation method which is the process that entails the gas hydrate decomposition into more simple components. In the case of the gas hydrates the dissociation takes place after the temperature increase and pressure reduction. As a result, the hydrate crystals start melting releasing the natural gas molecules and water entrapped inside the crystal. The choice of the most suitable method depends on the given deposit bedding conditions and also its physical, chemical and mechanical properties. At this, the gas extraction cost should be comparable to the natural gas market price.

It is known that the dissociation process of a methane hydrate with the help of a heatcarrier introduction consists of 4 stages:

a) swapping free methane with the help of water introduction;

b) additional formation of the methane hydrate in the zone of injection because of the dissociated water and gas migration;

c) real decomposition of the methane hydrate;

d) culmination of the dissociation.

However, as the experimental studies demonstrate, the thermal influence through the borehole face is low efficient [26, 27].

The analysis of the present technologies shows that the basic disadvantage of all heating methods is high energy consumption connected with heating the deposit. It should be considered that the phase transformation temperature of methane hydrate makes up not less than $7 \%$ from the calorific value of the released gas. At this, under the real conditions before the hydrate dissociation takes place the deposit should be heated up to the equilibrium temperature. However, thanks to the low thermal conductivity of gas hydrates and high thermal losses into the surrounding formations the face heaters usage is not efficient [28]. To provide more efficiency of the heat influence on the gas hydrate it is necessary to have a significant contact surface of the heat source with the hydrate that is connected with essential financial losses for the equipment.

According to the most world scientists' opinions, one of the perspective method of extraction is the artificial pressure lowering in the hydrate layer through boring a hole in it leading to the destabilisation of the whole bed. As a result of this method's realisation the bed pressure falls down, gas-saturated ice melts and the gas, entrapped in the hydrate, releases onto the surface [29]. 
Given method is only reasonable when hydrate saturation is not high and the gas or water have not lost its mobility. It is obvious that with hydrate saturation increase the efficiency of this method significantly reduces. Thus, when the pores are $80 \%$ saturated with hydrate it is almost impossible to get an influx from the latter using face pressure reduction.

The other disadvantage of this method is connected with the non-natural formation of hydrates in the near-face zone. In some hydrate deposits there are some areas where gas is in the free flowing condition. If to drill a borehole in that place the pressure in the layer will reduce. Providing this decrease is enough for the dissociation to start, then the gas release process will commence.

Considering the above-mentioned information about the existent methods for gas extraction from gas hydrates, it is obvious that none of these technologies provides a significant economic effect and safety of the process. In connection with that it is proposed to use the extraction technology supposing injection of carbon dioxide into the hydrate layer thus replacing methane onto the surface using physical-chemical properties and favourable thermodynamic parameters with parallel formation of the carbon dioxide hydrate $[30-32]$.

The suggested technology of two gases swap provides three critical advantages over other technologies:

1) safe extraction of methane since this method is implemented without using any heat carrier that is the phase equilibrium of the gas hydrate stays stable and thus hydrate dissociation does not occur;

2) this technology implies $\mathrm{CO}_{2}$ sequestration that is a powerful greenhouse gas. Hence, given method supports the control of global warming processes;

3) $\mathrm{CO}_{2}$ being introduced into the methane hydrate forms carbon dioxide hydrate simultaneously replacing methane. At this $\mathrm{CO}_{2}$-hydrate is a more stable structure compared to methane hydrate. That it is less exposed to fluctuations of the environmental temperature and pressure.

\section{Setting the research goal}

The aim of this work is the development of technological solutions for natural gas extraction from gas hydrate deposits with the help of inhibitors injection into the methane hydrate based on the experimental studies of their penetration rate.

To reach this goal the following tasks were solved:

- developing the complex methodical approach including the optimal pressure determination of two gases swap, experimental studies conduction as to the inhibitors penetration rate and design-and-engineering performance of the technological scheme for methane recovery;

- defining carbon dioxide penetration rate into the methane hydrate and thermobaric conditions of the process;

- presenting the possibility of this technological scheme implementation consisting of carbon dioxide injection replacing the methane from the hydrate.

\section{Methodology of research}

The studies were carried out in a laboratory of innovation technologies based in the Dnipro University of Technology. The laboratory possesses the necessary equipment suing which it is possible to study hydrate formation processes and also their further decomposition. The experiments are conducted on the modernised piece of equipment called NPO-5 using thermal chamber ILKA KTK-3000 [33 - 35]. This equipment allows us to use the kinetics 
of the hydrate formation process, simulation initial thermobaric parameters of hydrate formation, establish the ways of intensification of the formation process and examine physical-chemical peculiarities of received gas hydrates samples [36,37]. Also the laboratory equipment allows researching phase equilibrium and establishing thermobaric parameters of phase transformations of coalbed methane into hydrate state. This has given the possibility to come up with a hypothesis about sudden outbursts of gas based on gaseous methane in coal mines at depths of $1000 \mathrm{~m}$ and deeper, and about their explosive destruction connected with Percy Bridgman's effect [38].

The studies results that a given above were implemented in 3 stages. During the first stage it is necessary to define an optimal pressure of two gases swap based on minimal time of the process. It was established by us that while swapping these gases the pressure of carbon dioxide injection must be $20 \%$ higher than the one existing the preliminary created $\mathrm{CH}_{4}$ hydrate to provide the highest rate of the process. If this value is lower the swapping process takes too much time; if the value is to high - the replacement takes place only for not a significant distance since the $\mathrm{CO}_{2}$ hydrate is created too fast thus forming a hydrate plug through which the gas jet almost does not penetrate. As a result, the formula for calculating optimal pressure of the swap has been introduced:

$$
P_{\text {opt }}=P_{\text {reac }}+0.2 P_{\text {reac }},
$$

where $P_{\text {opt }}$ is optimal carbon dioxide injection pressure into the preliminary created hydrate, $\mathrm{MPa} ; P_{\text {reac }}$ is pressure initially present in the reactor, $\mathrm{MPa} ; 0.2$ is difference between the injection pressure and the one existing in the reactor $(20 \%)$.

Given formula is substantiated by the following way: initially the pressure in the reactor is set to $7.5 \mathrm{MPa}$. At this pressure the preliminarily created $\mathrm{CH}_{4}$ hydrate is stable. To remove methane out of this hydrate it is proposed to introduce carbon dioxide jet through this hydrate creating thus $\mathrm{CO}_{2}$ hydrate replacing methane in the reactor. So that the carbon dioxide jet interact with methane hydrate the former is necessary to be injected at a higher pressure compared to the one existing in the reactor. As a result of our previous laboratory studies, it turned out that the injection pressure should be $20 \%$ higher than the one existing in the reactor.

In the second stage we were defining the swapping process rate in the reactor under an optimal pressure and constant temperature of the environment. The studies were carried out while variating the optimal pressure from 5 to $10 \mathrm{MPa}$ and constant temperature being at $+7 \ldots+8{ }^{\circ} \mathrm{C}$. At this, the rate of swap was being continuously checked.

In the third stage the new technological solution as to methane recovery with help of $\mathrm{CO}_{2}$ introduction into the hydrate as a means of an inhibitor has been elaborated based on the dependencies received after $\mathrm{CO}_{2}$ penetration into methane hydrate.

\section{Results and discussion}

For more detailed understating of the swapping process in the preliminary created hydrate there are some schematic figures (Fig. 1). Fig. 1, $a$ portrays the system consisting of methane hydrate, water and free gas under equilibrium thermobaric parameters. Further (Fig. 1,b) carbon dioxide is introduced into the gas hydrate with the help of diffusion. Carbon dioxide, thanks to its physical properties described above, forms $\mathrm{CO}_{2}$ hydrate in the lower part of the methane hydrate. Thus, at this stage the stable system of two gas hydrates is created: methane and carbon dioxide. As the $\mathrm{CO}_{2}$ hydrate grows (Fig. 1,c) methane in free state is being pushed out of the system. The process continues until almost all space of the initial hydrate is filled with the hydrate of $\mathrm{CO}_{2}$ (Fig. 1,d). 

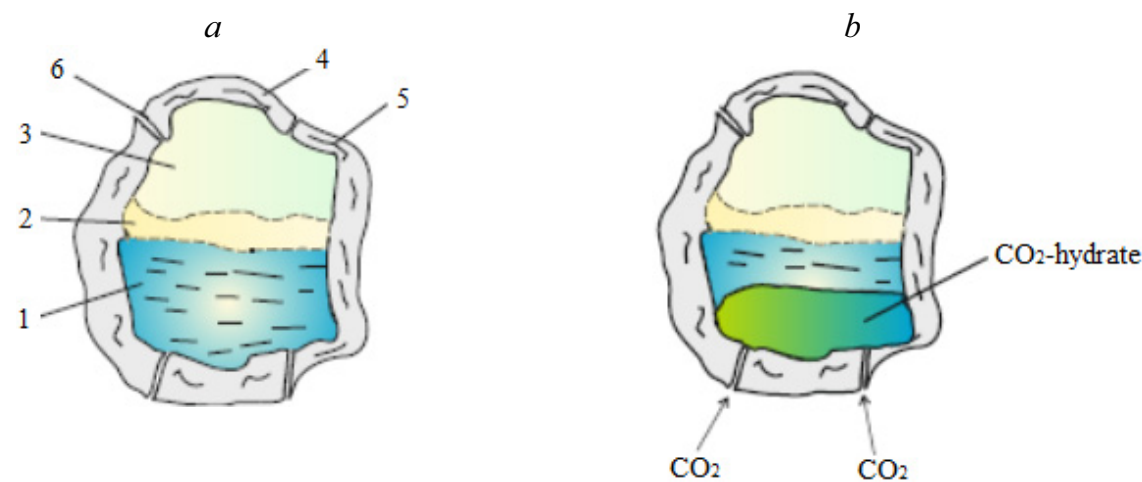

$c$
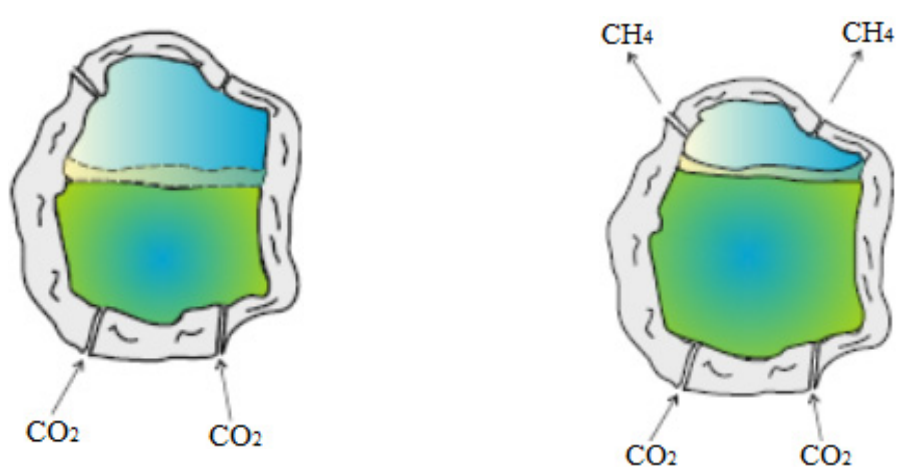

Fig. 1. Swapping mechanism of methane replacement with carbon dioxide in the methane hydrate with phases distribution: (a) equilibrium condition of methane hydrate; (b) phases distribution during $\mathrm{CO}_{2}$ introduction into the hydrate; (c) contact border between two phases in the hydrate; (d) $\mathrm{CO}_{2}$ hydrate growth and $\mathrm{CH}_{4}$ gas replacement; 1 - water; $2-\mathrm{CH}_{4}$ hydrate; $3-\mathrm{CH}_{4}$ gas; $4-$ host rock; $5-$ pores; 6 - channels between pores.

The swapping process of two gages in the methane hydrate is realised in three stages:

1) carbon dioxide hydrate on the contact with water;

2) two gas hydrate system formation $-\mathrm{CH}_{4}$ and $\mathrm{CO}_{2}$;

3) methane replacement by carbon dioxide hydrate.

The results of our studies on phase transitions substantiation taking place while swapping two gases in the preliminary created methane hydrate have shown that the complete exchange of host gas molecules in a solid hydrate can be achieved in 2 hours $\left(P=9 \mathrm{MPa}, T=+7 \ldots+8{ }^{\circ} \mathrm{C}\right)$ under the condition that values of pressure and temperature are monitored during the whole time of the experiment (Fig. 2). Length of the experimental reactor used for gases swapping is 1 meter. Also it was established that crystallisation centres nucleation of the $\mathrm{CO}_{2}$ hydrate took about $30-35$ minutes, after that the crystals continue growing replacing methane from the preliminary created methane hydrate until about $70-80 \%$ of the hydrate fills with $\mathrm{CO}_{2}$ hydrate.

Analysing the graph (Fig. 2), it was established that the optimal pressure for the maximum rate of gases swap at a constant temperature is $9 \mathrm{MPa}$. Pressures higher than $10 \mathrm{MPa}$ make the swapping process impossible because of the hydrate plug formation blocking the $\mathrm{CO}_{2}$ penetration into the existing hydrate. Thus, it was established that the swapping place lasted for only 45 minutes and then stopped. This fact has proved once again that when the pressure is too high $\mathrm{CO}_{2}$ penetration through a hydrate layer is blocked. 


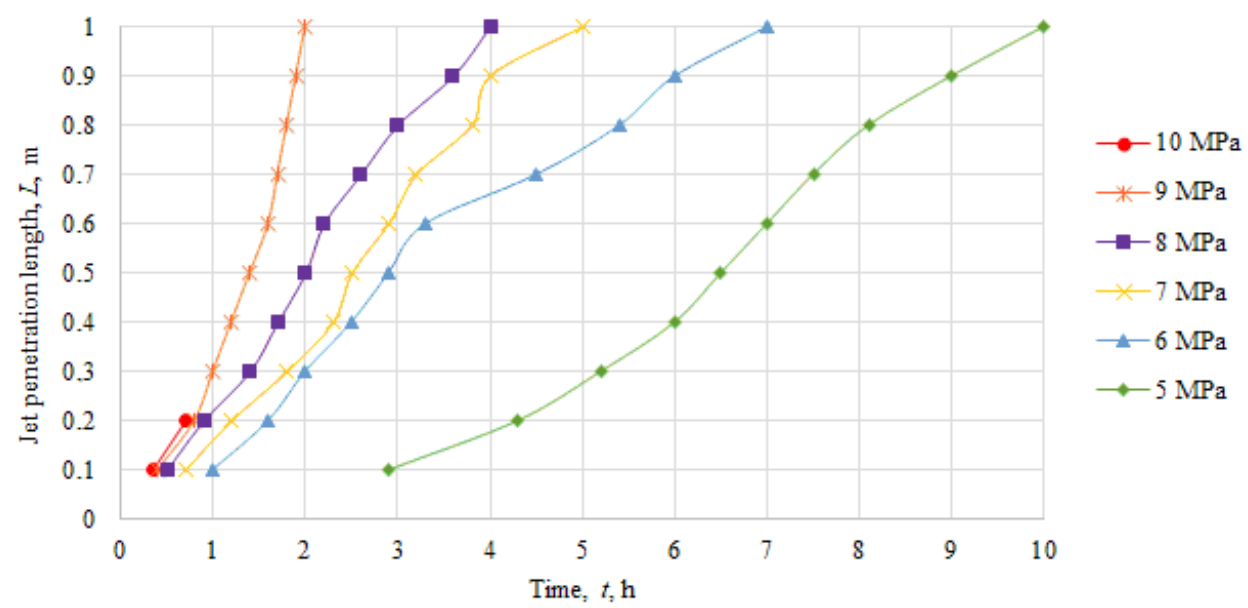

Fig. 2. $\mathrm{CO}_{2}$ jet penetration length into the methane hydrate dependence on time at constant temperature $T=+7 \ldots+8^{\circ} \mathrm{C}$ and variable pressure.

Also, as a result of the studies it was discovered that the pressure reduction for $1 \mathrm{MPa}$ leads to the decrease of the swapping process. At $P=8 \mathrm{MPa}$ the swapping process of the $\mathrm{CH}_{4}$ hydrate into $\mathrm{CO}_{2}$ hydrate finished in 4 hours that is 2 times longer than when using optimal pressure of $P=9 \mathrm{MPa}$. Similar situation was observed at pressures equal to 7,6 and $5 \mathrm{MPa}$. The lowest rate of swapping was at $P=5 \mathrm{MPa}$ that finished in 10 hours.

As a result of the studies directed to two gases swap the dependence of the jet penetration length $(L)$ on the time $(t)$ at the optimal injection pressure of $\mathrm{CO}_{2}$ was established and that is described by the following empirical equation:

$$
L=0.0662 e^{1.394 t} \text { and } R^{2}=0.9868 \text {. }
$$

As an object of the proposed technological solutions the most perspective gas hydrate deposit is selected that is located in the center of the Black Sea trough. The Sorokin's trough is considered to be the most predisposed area for gas hydrate formation processes and, hence, the most perspective one. It is situated $40 \mathrm{~km}$ to the South-East from Yalta [39-41]. About 30 mud volcanoes have been found there and gas torches of $800 \mathrm{~m}$ height have been noticed at the same area. The gas hydrate layer thickness to be recovered makes up $100 \mathrm{~m}$ [42]. Schematic lay-out of the gas hydrate layer in space is presented on Fig. 3 together with its thermobaric conditions of formation.

A few factors are assumed while developing the given deposit:

- the gas hydrate is considered to be a pure structure I of methane hydrate;

$-30 \%$ of the gas hydrate layer is taken up by rocks [43 -45$]$;

- recovery is carried out as a result of carbon dioxide jet penetration into the hydrate under definite technological parameters;

$-\mathrm{CO}_{2}$ injection pressure is higher than that existing the hydrate layer but lower than the pressure causing carbon dioxide liquefaction;

- physical properties of $\mathrm{CO}_{2}$ and methane hydrate are constant and depend only on technological parameters of exploitation;

- gas movement along the pipeline has a laminar flow;

- the pipeline wall temperature, pressure and the environmental temperature both at entrance and exit out of the pipe are constant;

- the excavated deposit is homogeneous and isotropic;

- the surface being under the influence of the jet is considered to be a plane. 


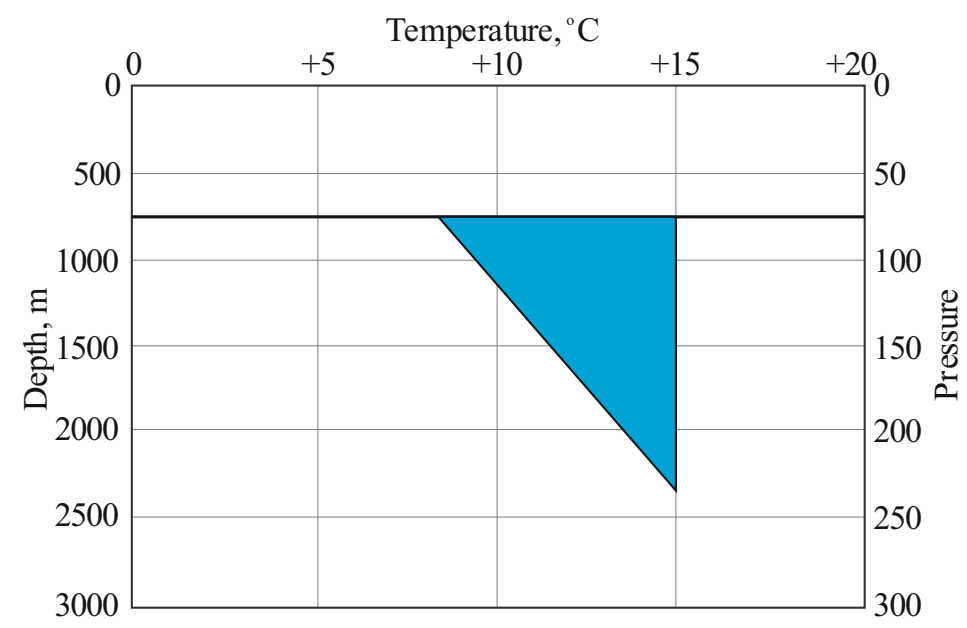

Fig. 3. The depth of the gas hydrate layer bedding in the Black Sea and its thermobaric conditions of formation [42].

As it has been already noted, to recover natural gas from the selected gas hydrate deposit it is proposed to use the swapping technology of methane into carbon dioxide inside the hydrate. $\mathrm{CO}_{2}$ is injected in order to regulate the bedding pressure, improve the recovery efficiency and create carbon dioxide hydrate in the end.

On Fig. 4 the above mentioned technology realisation is presented. The novelty of this technological solution is that the thickness of the gas hydrate layer is preliminary determined, also its pressure and temperature; the borehole is drilled under the level of its bedding then the $\mathrm{CO}_{2}$ is injected under the pressure higher than the existing pressure in the hydrate deposit and with temperature correspondent to the hydrate deposit's own temperature.

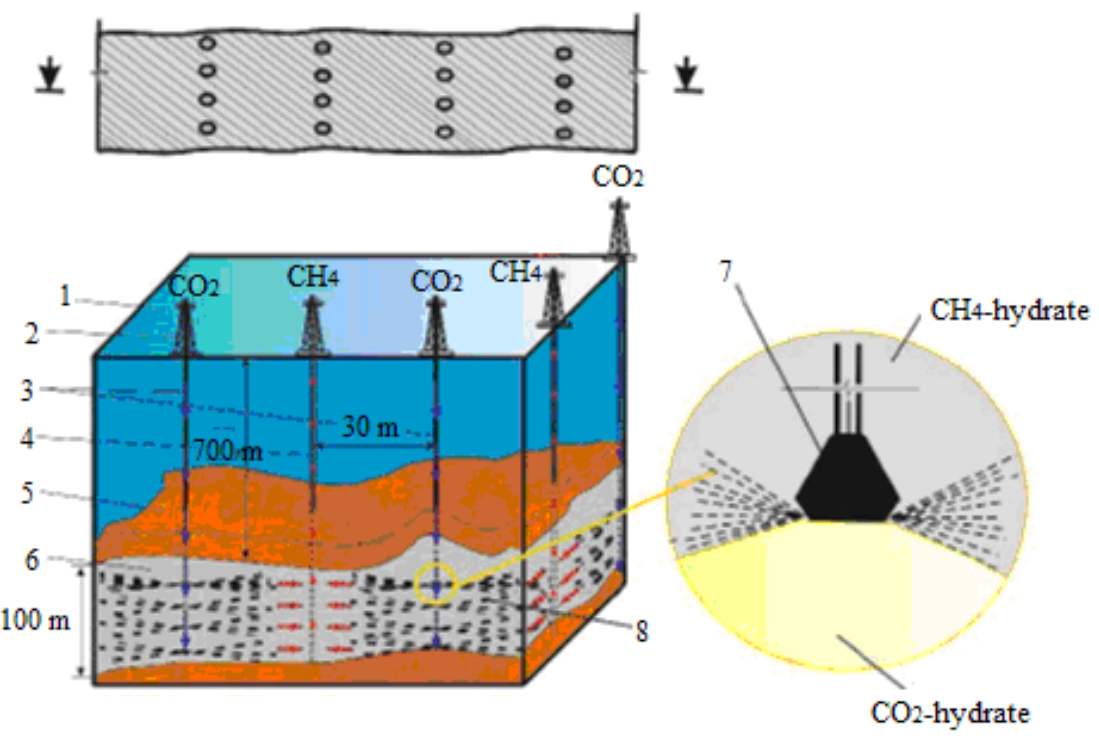

Fig. 4. Scheme of the methane recovery from the gas hydrate deposit replacing $\mathrm{CH}_{4}$ with carbon dioxide: 1 - sea surface; 2 - drilling rig; 3 - injection boreholes; 4 - production boreholes; 5 - sea bottom; 6 - gas hydrate layer; 7 - high-pressure nozzle; 8 - production zone; $\rightarrow$ flow of $\mathrm{CH}_{4} ; \rightarrow$ flow of $\mathrm{CO}_{2}$. 
The gas recovery technology is realised with the introduction of carbon dioxide along the pipeline to the lower border of the gas hydrate. Thus, the first stage is the selection of the gas hydrate layer considering its geological characteristics.

The thickness of the selected gas hydrate is preliminary determined and also its pressure. Two injection boreholes 3 are drilled across the whole thickness of the layer from the drill platform 1 located on the sea surface; simultaneously with this the production well 4 is drilled. After the injection well reaches the lower border of the gas hydrate layer, carbon dioxide is being introduced under a predefined pressure through a high-pressure nozzle 7 installed at the end of the borehole. The nozzle has two holes through which the gas is injected at an angle equal to $60^{\circ}$.

Thus, the gas jet released from the nozzles forms the production area of the gas hydrate 8. As the carbon dioxide is being injected into the gas hydrate face, the $\mathrm{CO}_{2}$ hydrate is gradually formed squeezing methane out towards the production well 4 . Vacuum pressure is created as the production area line moves towards the production well 4 . After reaching the production well 4 in a definite time the removed methane is pumped onto the surface through borehole 3. After this the pipeline is lifted along the borehole 4 for a predefined length and the $\mathrm{CO}_{2}$ injection and $\mathrm{CH}_{4}$ recovery takes place again.

Gas hydrate deposit extraction is performed upwards. The high-pressure jet injection promotes the necessary activation degree of the swapping process the main gas of which is methane $(93-98 \%)[46,47]$. Two parallel process take place simultaneously: methane replacement and $\mathrm{CO}_{2}$ hydrate formation.

A special device (chromatograph) situated on the floating platform provides the information about gas content released on the surface and, based on the results of which, methane recovery efficiency is defined.

\section{Conclusions}

1. Analysis of the literature and information resources concerning industrial excavation of natural gas hydrate deposits testifies about low efficiency of the existing methods of gas recovery from gas hydrates, namely, low economic effect and safety of gas extraction. Hence, an alternative method of gas recovery is considered in present work assuming inhibitors injection into the hydrate layer, particularly, $\mathrm{CO}_{2}$.

2. As a result of experimental studies of $\mathrm{CO}_{2}$ penetration into gas hydrate it was determined that the full replacement of host molecules in a solid hydrate can be maximally reached in 2 hours $\left(P=9 \mathrm{MPa}, T=+7 \ldots+8^{\circ} \mathrm{C}\right)$ providing the temperature and pressure being controlled during the whole duration of the experiment.

3. It is established that the crystallisation centres nucleation of carbon dioxide hydrate takes about $30-35 \mathrm{~min}$ and after that the crystals continue growing replacing methane from the preliminary create methane hydrate until about $70-80 \%$ hydrate is filled with $\mathrm{CO}_{2}$ hydrate.

4. It has been discovered that the pressure reduction for just $1 \mathrm{MPa}$ promotes decrease of swapping rate. It has also been established that at pressures higher than $10 \mathrm{MPa}$ the process of methane hydrate swap becomes impossible because of the hydrate clog formation that blocks $\mathrm{CO}_{2}$ penetration into the existing hydrate.

5. A new technologic scheme of methane recovery from gas hydrate deposits is introduced with the help of $\mathrm{CO}_{2}$ injection into the formation that is different from the other known methods by the fact that the hydrate deposit thickness is preliminary defined together with its pressure and temperature; a borehole is drilled under the level of the extracted hydrate layer, $\mathrm{CO}_{2}$ is injected into the well with the pressure higher than the existing in the hydrate layer and with temperature correspondent to the hydrate deposit's own temperature. 
The results have been received within the frame of the implemented scientific research project "Synthesis, optimization and parameterization of innovative technologies for coal-gas deposits mining" (State registration No. 0119U000248).

\section{References}

1. Resources to reserves 2013 - oil, gas and coal technologies for the energy markets of the future. (2013). Paris: International Energy Agency.

2. Statistical review of World energy. (2015). London: Centre for Energy Economics Research and Policy, Pureprint Group Limited.

3. Adhikari, D. (2018). Solar energy as an alternative source of energy. Bibechana, (2), 1-7. https://doi.org/10.3126/bibechana.v2i0.19227

4. Hepbasli, A. (2004). Oil shale as an alternative energy source. Energy Sources, 26(2), 107-118. https://doi.org/10.1080/00908310490258489

5. Wind power as an alternative energy source. (2008). Physics Today. https://doi.org/10.1063/pt.5.022269

6. Khorolskyi, A., Hrinov, V., \& Kaliushenko, O. (2019). Network models for searching for optimal economic and environmental strategies for field development. Procedia Environmental Science, Engineering and Management, 6(3), 463-471.

7. Kuzmenko, O., Petlyovanyy, M., \& Heylo, A. (2014). Application of fine-grained binding materials in technology of hardening backfill construction. Progressive Technologies of Coal, Coalbed Methane, and Ores Mining, 465-469. https://doi.org/10.1201/b17547-79

8. Petlovanyi, M., Lozynskyi, V., Saik, P., \& Sai, K. (2019). Predicting the producing well stability in the place of its curving at the underground coal seams gasification. E3S Web of Conferences, (123), 01019. https://doi.org/10.1051/e3sconf/201912301019

9. Sotskov, V., Dereviahina, N., \& Malanchuk, L. (2019). Analysis of operation parameters of partial backfilling in the context of selective coal mining. Mining of Mineral Deposits, 13(4), 129138. https://doi.org/10.33271/mining13.04.129

10. Petlovanyi, M., Lozynskyi, V., Zubko, S., Saik, P., \& Sai, K. (2019). The influence of geology and ore deposit occurrence conditions on dilution indicators of extracted reserves. RudarskoGeološko-Naftni Zbornik, 34(1), 83-91. https://doi.org/10.17794/rgn.2019.1.8

11. Natural gas production. (2013). Oil and Energy Trends, 38(1), 24-26. https://doi.org/10.1111/oet.12037_4

12. Sai, K., Malanchuk, Z., Petlovanyi, M., Saik, P., \& Lozynskyi, V. (2019). Research of thermodynamic conditions for gas hydrates formation from methane in the coal mines. Solid State Phenomena, (291), 155-172. https://doi.org/10.4028/www.scientific.net/ssp.291.155

13. Bondarenko, V., Ganushevych, K., Sai, K., \& Tyshchenko, A. (2011). Development of gas hydrates in the Black sea. Technical and Geoinformational Systems in Mining, 55-59. https://doi.org/10.1201/b11586-11

14. Petlovanyi, M.V., \& Medianyk, V.Y. (2018). Assessment of coal mine waste dumps development priority. Naukovyi Visnyk Natsionalnoho Hirnychoho Universytetu, (4), 28-35. https://doi.org/10.29202/nvngu/2018-4/3

15. Max, M.D., \& Johnson, A.H. (2016). Commercial potential of natural gas hydrate. Exploration and Production of Oceanic Natural Gas Hydrate, 355-394. https://doi.org/10.1007/978-3-31943385-1_11

16. Hancock, S., Boswell, R., \& Collett, T. (2019). Development of deepwater natural gas hydrates. Offshore Technology Conference. https://doi.org/10.4043/29374-ms

17. Rogers, R. (2015). Producing methane from offshore hydrates. Offshore Gas Hydrates, 101133.e1. https://doi.org/10.1016/b978-0-12-802319-8.00004-8

18. Bondarenko, V., Sai, K., Prokopenko, K., \& Zhuravlov, D. (2018). Thermodynamic and geomechanical processes research in the development of gas hydrate deposits in the conditions of 
the Black Sea. Mining of Mineral Deposits, 12(2), 104-115. https://doi.org/10.15407/mining12.02.104

19. Bondarenko, V.I., \& Sai, K.S. (2018). Process pattern of heterogeneous gas hydrate deposits dissociation. Naukovyi Visnyk Natsionalnoho Hirnychoho Universytetu, (2), 21-28. https://doi.org/10.29202/nvngu/2018-2/4

20. Korsakov, O.D., Stupak, S.N., \& Byakov, Yu.A. (1991). Black Sea gas hydrates are an unconventional type of hydrocarbon raw. Geologicheskiy Zhurnal, (5), 67-75.

21. Merey, S., \& Sinayuc, C. (2016). Analysis of the Black Sea gas hydrates. International Journal of Chemical and Molecular Engineering, 10(8), 985-993.

22. Makogon, Y.F., Holditch, S.A., \& Makogon, T.Y. (2007). Natural gas-hydrates - a potential energy source for the 21st century. Journal of Petroleum Science and Engineering, 56(1-3), 1431. https://doi.org/10.1016/j.petrol.2005.10.009

23. Yang, X.G., \& Qin, M.J. (2012). Natural gas hydrate as potential energy resources in the future. Advanced Materials Research, (462), 221-224. https://doi.org/10.4028/www.scientific.net/amr.462.221

24. Methane gas hydrate: as a natural gas source. (2010). Green Energy and Technology, 113-160. https://doi.org/10.1007/978-1-84882-872-8 4

25. Max, M.D., \& Johnson, A.H. (2016). Energy overview: prospects for natural gas. Exploration and Production of Oceanic Natural Gas Hydrate, 1-38. https://doi.org/10.1007/978-3-319-43385-1_1

26. Vasil'eva, Z.A., \& Yakushev, V.S. (2017). Influence of gas well thermal insulation parameters on thawing intensity of permafrost and intrapermafrost gas hydrates. Kriosfera Zemli, (5), 92-98. https://doi.org/10.21782/kz1560-7496-2017-5(92-98)

27. Carroll, J. (2014). Combating hydrates using heat and pressure. Natural Gas Hydrates, 197-229. https://doi.org/10.1016/b978-0-12-800074-8.00007-7

28. Gornitz, V., \& Fung, I. (1994). Potential distribution of methane hydrates in the world's oceans. Global Biogeochemical Cycles, 8(3), 335-347. https://doi.org/10.1029/94gb00766

29. Gupta, A., \& Aggarwal, A. (2014). Gas hydrates extraction by swapping-depressurisation method. Offshore Technology Conference-Asia. https://doi.org/10.4043/24819-ms

30. Jadhawar, P., Mohammadi, A.H., Yang, J., \& Tohidi, B. (n.d.). Subsurface carbon dioxide storage through clathrate hydrate formation. Advances in the Geological Storage of Carbon Dioxide, 111126. https://doi.org/10.1007/1-4020-4471-2 11

31. Zheng, J., Loganathan, N.K., \& Linga, P. (2019). Natural gas storage via clathrate hydrate formation: Effect of carbon dioxide and experimental conditions. Energy Procedia, (158), 55355540. https://doi.org/10.1016/j.egypro.2019.01.590

32. Khasanov, M.K. (2017). Mathematical model of formation of carbon dioxide hydrate upon injection of carbon dioxide into a methane hydrate stratum. Theoretical Foundations of Chemical Engineering, 51(5), 647-657. https://doi.org/10.1134/s004057951705030x

33. Ovchynnikov, M., Ganushevych, K., \& Sai, K. (2013). Methodology of gas hydrates formation from gaseous mixtures of various compositions. Annual Scientific-Technical Collection - Mining of Mineral Deposits 2013, 203-206. https://doi.org/10.1201/b16354-36

34. Bondarenko, V., Sai, K., Ganushevych, K., \& Ovchynnikov, M. (2015). The results of gas hydrates process research in porous media. New Developments in Mining Engineering 2015: Theoretical and Practical Solutions of Mineral Resources Mining, 123-127. https://doi.org/10.1201/b19901-23

35. Bondarenko, V., Svietkina, O., \& Sai, K. (2018). Effect of mechanoactivated chemical additives on the process of gas hydrate formation. Eastern-European Journal of Enterprise Technologies, 1(6(91)), 17-26. https://doi.org/10.15587/1729-4061.2018.123885

36. Ganushevych, K., Sai, K., \& Korotkova, A. (2014). Creation of gas hydrates from mine methane. Progressive Technologies of Coal, Coalbed Methane, and Ores Mining, 505-509. https://doi.org/10.1201/b17547-85 
37. Bondarenko, V., Svietkina, O., \& Sai, K. (2017). Study of the formation mechanism of gas hydrates of methane in the presence of surface-active substances. Eastern-European Journal of Enterprise Technologies, 5(6 (89)), 48-55. https://doi.org/10.15587/1729-4061.2017.112313

38. Bondarenko, V., Kovalevska, I., Astafiev, D., \& Malova, O. (2018). Examination of phase transition of mine methane to gas hydrates and their sudden failure - Percy Bridgman's effect. Solid State Phenomena, (277), 137-146. https://doi.org/10.4028/www.scientific.net/ssp.277.137

39. Vasil'yev, A., \& Dimitrov, L. (2002). Otsenka prostranstvennogo raspredeleniya i zapasov gazogidratov v Chernom more. Geologiya i Geofizika, 7(43), 61-67.

40. Starostenko, V.I., Rusakov, O.M., Shnyukov, E.F., Kobolev, V.P., \& Kutas, R.I. (2010). Methane in the northern Black Sea: characterization of its geomorphological and geological environments. Geological Society, London, Special Publications, 340(1), 57-75. https://doi.org/10.1144/sp340.5

41. Kobolev, V. (2017). Structural, tectonic and fluid-dynamic aspects of deep degassing of the black sea megatrench. Mining of Mineral Deposits, 11(1), 31-49. https://doi.org/10.15407/mining11.01.031

42. Makogon, Yu.F. (2010). Gazogidraty. Istoriya izucheniya i perspektivy osvoeniya. Geologiya $i$ Poleznye Iskopaemye Mirovogo Okeana, (2), 5-21.

43. Vasil'yev, V.I., Popov, V.V., \& Tsypkin, G.G. (2006). Chislennoe issledovanie razlozheniya gazovykh gidratov, sosushchestvuyushchikh $\mathrm{s}$ gazom $\mathrm{v}$ prirodnykh plastakh. Izvestiya RAN. Mekhanika Zhidkosti Gaza, (4), 127-134.

44. Popescu, I., Lericolais, G., Panin, N., De Batist, M., \& Gillet, H. (2007). Seismic expression of gas and gas hydrates across the western Black Sea. Geo-Marine Letters, 27(2-4), 173-183. https://doi.org/10.1007/s00367-007-0068-0

45. Yang, M., Song, Y., Liu, Y., Chen, Y., \& Li, Q. (2010). Influence of pore size, salinity and gas composition upon the hydrate formation conditions. Chinese Journal of Chemical Engineering, 18(2), 292-296. https://doi.org/10.1016/s1004-9541(08)60355-9

46. Ginsburg, G.D., Kremlev, A.N., \& Grigor'yev, M.N. (1989). Otkrytie fil'trogennykh gazovykh gidratov na Prikrymskom kontinental'nom podnozhii. Doklady AN SSSR, 309(2), 409-411.

47. Ivanov, M.K., Limonov, A.F., \& Woodside, J.M. (1998). Extensive deep fluid flux through the sea floor on the Crimean continental margin (Black Sea). Geological Society, London, Special Publications, 137(1), 195-213. https://doi.org/10.1144/gsl.sp.1998.137.01.16 